\title{
Evaluation of serum L-FABP levels in patients with acute pancreatitis
}

\author{
Erdem Koçak, M.D., ${ }^{1}$ Erdem Akbal, M.D., ${ }^{2}$ Seyfettin Köklü, M.D., ${ }^{3}$ Gürhan Adam, M.D. ${ }^{4}$
}

\author{
${ }^{1}$ Department of Gastroenterology, Çanakkale State Hospital, Çanakkale; \\ ${ }^{2}$ Department of Gastroenterology, Çanakkale Onsekizmart University Faculty of Medicine, Çanakkale; \\ ${ }^{3}$ Department of Gastroenterology, Hacettepe University Faculty of Medicine, Ankara; \\ ${ }^{4}$ Department of Radiology, Çanakkale Onsekizmart University Faculty of Medicine, Çanakkale
}

\begin{abstract}
BACKGROUND: The aim of this study was to assess the serum L-FABP levels in patients with acute pancreatitis and compare with healthy subjects.

METHODS: Thirty patients with acute pancreatitis and thirty consecutive healthy age- and sex-matched control subjects were included into the study. The serum levels of L-FABP were measured upon admission and at the remission period.

RESULTS: Upon admission, serum L-FABP concentration was significantly higher in patients with acute pancreatitis compared to control subjects $(4 \mathrm{I} 009.4 \mathrm{I} \pm 3240 \mathrm{I} .3 \mathrm{I} \mathrm{pg} / \mathrm{ml}$ vs. $17057.00 \pm 50 \mathrm{I} 5.74 \mathrm{pg} / \mathrm{ml}, \mathrm{p}=0.008)$. Serum L-FABP levels decreased after the remission period; however, the differences were not statistically significant. In addition, serum L-FABP levels showed significant correlation with AST and LDH levels.
\end{abstract}

CONCLUSION: Increased serum L-FABP levels may be related to the mechanism of pancreatic microcirculatory disturbance in patients with acute pancreatitis, suggesting that serum L-FABP could be used for a potential biomarker of acute pancreatitis.

Key words: Acute pancreatitis; diagnosis; serum L-FABP.

\section{INTRODUCTION}

Acute pancreatitis is an inflammatory disease associated with auto digestion of the pancreas due to intra-pancreatic activation and the release of digestive enzymes. Most patients suffer from mild disease but in about $20 \%$ of the cases, the patient develops a severe form of the disease with a mortality of $7-15 \%$. A number of biochemical markers have been used in the diagnosis of acute pancreatitis. ${ }^{[1-3]}$ Several of these markers have been documented to be present at increased concentrations in the plasma of patients with acute pancreatitis.

Fatty acid binding proteins (FABPs) are a group of low mo-

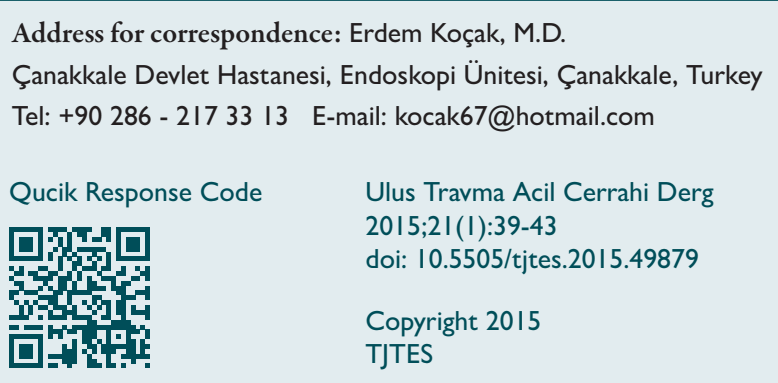

lecular weight $(14-15 \mathrm{k} \mathrm{dal})$ proteins involved in the intracellular transport of long chain bioactive fatty acids. ${ }^{[4]}$ Being abundantly low molecular cytoplasmic proteins with tissue specific expression profiles, FABPs serve as markers of tissue injury. Various FABPs have been tested to detect the early damage of tissues with a clinical utility in view. If damage process continues, FABP is detectable in serum. ${ }^{[5-7]}$

In the course of acute pancreatitis development, oxygenfree radicals and their derivatives play an important role as the molecular trigger in constituting lesions in the pancreas. Damaged acinar cells as well as activated neutrophils and macrophages produce large amounts of oxygen radicals in acute pancreatitis. Hydrogen peroxide, superoxide, hydroxyl radical, and singlet oxygen are key elements capable of cellular injury in acute pancreatitis. These highly reactive species cause various reactions, such as destruction of lipid membranes by peroxidation of fatty acids and destruction of lysosomal membranes. ${ }^{[8]}$ Liver fatty acid-binding protein (L-FABP) binds selectively to intracellular free unsaturated fatty acids and lipid peroxidation products during hypoxic tissue injury. Therefore, L-FABP may modulate inflammatory responses in acute pancreatitis. However, the involvement of L-FABP in acute pancreatitis is not known yet. 
Table I. Demographic characteristics of the patients with acute pancreatitis and the control group

\begin{tabular}{lccc}
\hline & $\begin{array}{c}\text { Control group } \\
(\mathbf{n}=\mathbf{3 0})\end{array}$ & $\begin{array}{c}\text { Acute pancreatitis group } \\
(\mathbf{n}=\mathbf{3 0})\end{array}$ & $\mathbf{p}$ \\
\hline Age, years & $46.6 \pm 16.6$ & $53.9 \pm 19.4$ & 0.125 \\
Male/Female & $12 / 18$ & $11 / 19$ & 0.763 \\
BMI $\left(\mathrm{kg} / \mathrm{m}^{2}\right)$ & $27.3 \pm 4.1$ & $27.2 \pm 4.1$ & 0.942 \\
Smoking & $3.3 \%(n=1)$ & $16.6 \%(n=5)$ & 0.07 \\
Hypertension & $6.6 \%(n=2)$ & $13.3 \%(n=4)$ & 0.379 \\
Hyperlipidemia & $3.3 \%(n=1)$ & $13.3 \%(n=4)$ & $\mathbf{0 . 0 1 5 ^ { * }}$ \\
\hline
\end{tabular}

This study aimed to evaluate serum L-FABP levels in patients with acute pancreatitis and the changes of the serum L-FABP levels at the acute phase and after remission period.

\section{MATERIALS AND METHODS}

The study protocol was approved by Ankara Education and Research Hospital and was performed in accordance with the guidelines of the Declaration of Helsinki and its current revision. Written informed consent was obtained from patients and controls before the research. Thirty patients with a diagnosis of acute pancreatitis were included into the study. The diagnosis was established on the basis of acute abdominal pain, at least 3-fold elevated levels of serum amylase, and computed tomography (CT). All patients had no previous history of acute pancreatitis and were hospitalized with palliative management. According to the Atlanta criteria, the severity of acute pancreatitis was mild in all of them. Blood samples were obtained from each subject upon admission. In order to examine changes in serum L-FABP levels, blood samples were taken again after improvement in clinical and laboratory findings. The control group consisted of thirty healthy subjects. L-FABP, amylase, lipase, lactate dehydrogenase (LDH), hemogram, erythrocyte sedimentation rate (ESR), C-reactive protein (CRP), serum glucose, blood urea nitrogen, creatinine, serum lipid parameters, calcium, aspartate transaminase (AST), alanine transaminase (ALT), alkaline phosphatase, gamma glutamyl transpeptidase, total bilirubin, direct bilirubin, and albumin were measured in both groups. L-FABP was measured with a sandwich ELISA method with HyCult Biotechnology. The detection limit of the assay was $100.000 \mathrm{pg} / \mathrm{ml}$.

All results were expressed as mean 4+-SD. All scores were recorded on a database and analyzed using SPSS 16.0 packaged programs. Chi-square, sample T, Kruskal Wallis test and Mann-Whitney $U$ tests were used to compare the differences between the two groups. The significance of the linear correlation between continuous variables was evaluated with the Spearman correlation test. $P$ value $<0.05$ was accepted as statistically significant.

\section{RESULTS}

A total of thirty patients with acute pancreatitis and thirty control subjects were evaluated for plasma levels of L-FABP. Among the patients with acute pancreatitis, the most common cause was gallstone $(20 / 30,66.6 \%)$ and the second was alcohol (10/30, 33.3\%). The demographic features of the patients included into the study are summarized in Table I. There were no significant differences between acute pancreatitis and control group with respect to age, gender, hypertension, smoking status and BMI $(p>0.05)$. The only significant demographic difference was hyperlipidemia.

Serum L-FABP levels were significantly higher in patients with acute pancreatitis compared to control subjects (Fig. I). Mean serum L-FABP levels were $41009.41 \pm 32401.31 \mathrm{pg} / \mathrm{ml}$ in patients with acute pancreatitis and $17057.00 \pm 5015.74 \mathrm{pg} / \mathrm{ml}$ in those in the control $(p=0.008)$ (Table 2).

Although serum L-FABP levels decreased after the remission period, the differences were not statistically significant (Fig. I). The laboratory tests of the patients with acute pancreatitis and control group are summarized in Table 2 .

Correlations between serum L-FABP levels and clinical and laboratory parameters were also tested to evaluate the potential role of serum L-FABP levels in the diagnosis of acute

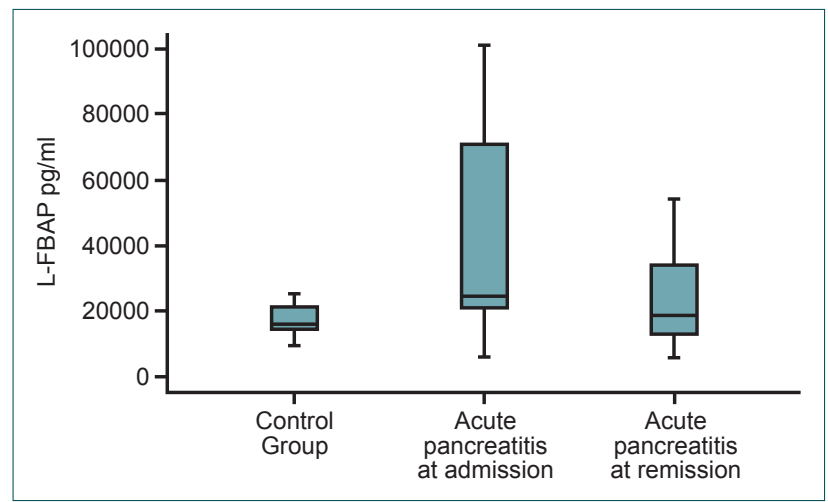

Figure 1. Serum L-FABP levels of the patients jith acute pancreatitis at admission and remission, and the control. 
Table 2. Laboratory tests of the patients with acute pancreatitis and control group

\begin{tabular}{|c|c|c|c|}
\hline \multirow[t]{2}{*}{ Variable } & \multirow{2}{*}{$\begin{array}{c}\text { Control group } \\
\text { Mean } \pm S D\end{array}$} & \multirow{2}{*}{$\begin{array}{l}\begin{array}{l}\text { Acute pancreatitis group, } \\
\text { at admission }\end{array} \\
\text { Mean } \pm \text { SD }\end{array}$} & \multirow[t]{2}{*}{$\mathbf{p}$} \\
\hline & & & \\
\hline Liver fatty acid-binding protein & $17057.00 \pm 50 \mid 5.74$ & $4|009.4 I \pm 3240| .3 \mid$ & 0.008 \\
\hline White blood cell & $6.750 \pm 1.60$ & $11.75 \pm 5.11$ & $<0.001$ \\
\hline Platelet count & $258.12 \pm 51.86$ & $225 \pm 59.57$ & 0.04 \\
\hline Hemoglobin & $13.8 \pm 1.6$ & $12.3 \pm 1.8$ & 0.05 \\
\hline Aspartate transaminase (U/L) & $20.6 \pm 3.8$ & $122 \pm 97.4$ & $<0.001$ \\
\hline Lactate dehydrogenase (U/L) & $194.3 \pm 41.7$ & $327.2 \pm 97.2$ & $<0.001$ \\
\hline Amylase (U/L) & $69.2 \pm 22.1$ & $852 \pm 491$ & $<0.001$ \\
\hline Lipase (U/L) & $17.2 \pm 13.9$ & $666.2 \pm 542.7$ & $<0.001$ \\
\hline Glucose (mg/dl) & $91.7 \pm 8.4$ & $103.7 \pm 29.7$ & 0,062 \\
\hline Blood urea nitrogen $(\mathrm{mg} / \mathrm{dl})$ & $30.6 \pm 15.4$ & $26.7 \pm 20.8$ & 0.463 \\
\hline Albumin $(g / l)$ & $4.3 \pm 0.27$ & $3.5 \pm 0.4$ & $<0.001$ \\
\hline Calcium (mg/dl) & $9.8 \pm 0.5$ & $8.5 \pm 0.6$ & $<0.001$ \\
\hline C-reactive protein (mg/dl) & $0.45 \pm 0.37$ & $8.6 \pm 7.42$ & $<0.001$ \\
\hline
\end{tabular}

Data expressed as mean \pm standard deviation. ${ }^{*} \mathrm{p}<0.05$

pancreatitis. There were no correlations between serum L-FABP levels and clinical parameters including age, gender, Body Mass Index (BMI), smoking, hypertension, and hyperlipidemia. Serum L-FABP levels were not correlated with amylase, lipase and CRP. However, serum L-FABP levels showed significant correlation with ALT, AST, ALP, GGT, LDH and total bilirubin (Table 3). Using serum LFAB-P levels, the area under the ROC curve for detecting acute pancreatitis was $0.72,95 \% \mathrm{Cl}, 0.53-0.90$. The cut-off value of serum LFAB-P for the detection of acute pancreatitis was 20260 pg/ml, sensitivity was $76 \%$, and specificity was $70 \%$ (Fig. 2 ).

\section{DISCUSSION}

In this study, serum L-FABP levels were found to be significantly increased in patients with acute pancreatitis as compared to healthy subjects. Serum L-FABP levels were shown

Table 3. Correlations between serum liver fatty acid-binding protein levels and laboratory parameters of the patients with acute pancreatitis

\begin{tabular}{lcc}
\hline & R Spearman & p \\
\hline Alanine transaminase & 0.523 & $<0.00$ I \\
Aspartate transaminase & 0.620 & $<0.00$ I \\
Alkaline phosphatase & 0.424 & $\mathbf{0 . 0 0 I}$ \\
Gama-glutamyl transferase & 0.467 & $<0.00$ I \\
Lactate dehydrogenase & 0.506 & $<0.00$ I \\
T.bilirubin & 0.403 & 0.003 \\
\hline
\end{tabular}

to decrease after remission period although the differences were not statistically significant.

Fatty-acid trafficking in cells is a complex and dynamic process affecting many aspects of cellular function. Fatty acids function both as an energy source and signals for metabolic regulation, acting through enzymatic and transcriptional networks to modulate gene expression, growth and survival pathways, and inflammatory and metabolic responses. L-FABP is known to bind polyunsaturated fatty acids ${ }^{[9]}$ and long-chain fatty acid

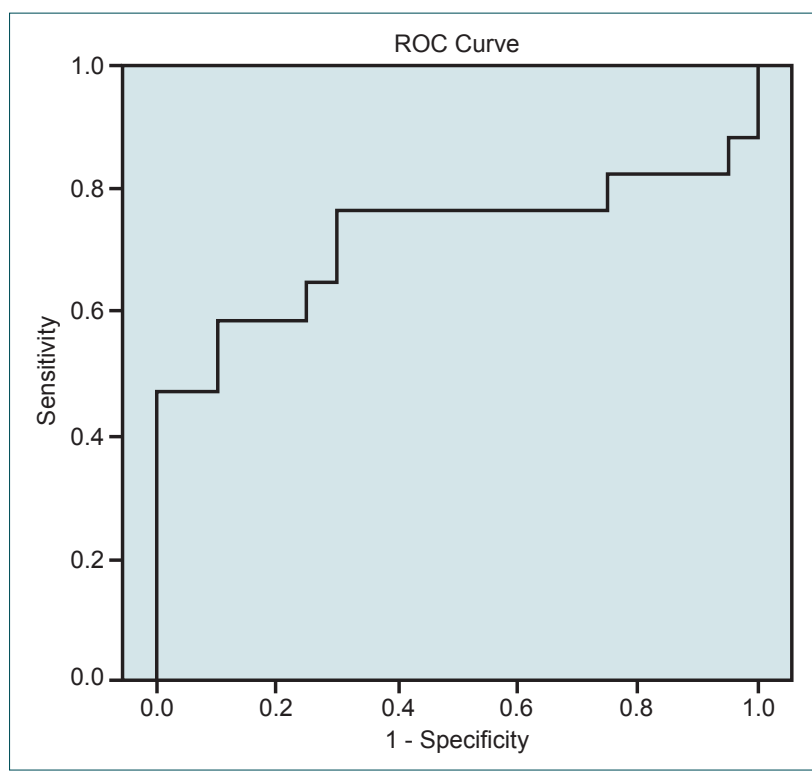

Figure 2. ROC curves for LFAB-P as diagnostic tests for acute pancreatitis. 
peroxidation products. ${ }^{[10]}$ Sztefko et al. have suggested that high serum free fatty acid concentration may be involved in the development of complications in acute pancreatitis. ${ }^{[1]}$ By binding polyunsaturated fatty acids, L-FABP modulates the availability of these fatty acids to intracellular oxidative pathways. In addition to these well-known functions, recent studies have shown that L-FABP plays a protective role in kidney injury. ${ }^{[12,13]}$ From a theoretical point, it was suggested that high levels of L-FABP could protect against oxidative stress and inflammation in the pancreatic tissue.

CRP is one of the acute phase reactants made by the liver in response to the release of interleukin-I and interleukin-6. Most authors have put forward that CRP is a valuable marker in the early assessment of the severity of acute pancreatitis. [14] Other mutiple serum markers have been studied so as to predict the severity of pancreatitis including urinary trypsinogen activation peptide, procalcitonin, polymorphonuclear elastase, pancreatic-associated protein, amylase and lipase, serum glucose, serum creatinine and calcium, procarboxypeptidase-B, carboxypeptidase $B$ activation peptide, serum trypsinogen-2, phospholipase A-2, serum amyloid protein-A, substance $P$, antithrombin III, platelet activating factor, interleukins 1, 6, and 8, tumor necrosis factor-alpha or soluble tumor necrosis factor receptor, and various genetic polymorphisms. ${ }^{[15,16]}$ L-FABP is predominantly found in the liver and thought to be involved in the regulation of lipid transport and metabolism. Research has shown L-FABP levels to rise significantly after cell damage. ${ }^{[17]}$ Similarly, in this study, significantly high serum L-FABP levels were found in patients with acute pancreatitis compared with the controls. Furthermore, serum L-FABP levels were shown to decrease after the remission period. However, the differences between LFABP levels in acute attack and after remission did not reach statistical significance. In our study, the serum L-FABP levels were evaluated in the early period of remission and this result can be explained by this methodological limitation. On the other hand, serum L-FABP level was not correlated with amylase, lipase and CRP levels, while it was significantly correlated with liver damage enzymes including ALT, AST, ALP, GGT, LDH and total bilirubin. Regarding these results, serum L-FABP was suggested a useful marker especially in patients with acute biliary and alcoholic pancreatitis independent of serum biomarkers of acute pancreatitis.

L-FABP may be a useful serum marker for the diagnosis of acute pancreatitis. This is the first study showing that patients with acute pancreatitis have higher serum L-FABP levels than healthy subjects. However, further clinical and experimental studies are needed to evaluate diagnostic and prognostic value of serum L-FABP levels in acute pancreatitis.
Conflict of interest: None declared.

\section{REFERENCES}

1. Puolakkainen P, Valtonen V, Paananen A, Schröder T. C-reactive protein (CRP) and serum phospholipase A2 in the assessment of the severity of acute pancreatitis. Gut 1987;28:764-71. CrossRef

2. Domínguez-Muñoz JE, Carballo F, García MJ, de Diego JM, Rábago L, Simón MA, et al. Clinical usefulness of polymorphonuclear elastase in predicting the severity of acute pancreatitis: results of a multicentre study. Br J Surg 1991;78:1230-4. CrossRef

3. Gudgeon AM, Heath DI, Hurley P, Jehanli A, Patel G, Wilson C, et al. Trypsinogen activation peptides assay in the early prediction of severity of acute pancreatitis. Lancet 1990;335:4-8. CrossRef

4. Glatz JF, van der Vusse GJ. Cellular fatty acid-binding proteins: their function and physiological significance. Prog Lipid Res 1996;35:243-82.

5. Akbal E, Özbek M, Güneş F, Akyürek Ö, Üreten K, Delibaşı T. Serum heart type fatty acid binding protein levels in metabolic syndrome. Endocrine 2009;36:433-7. CrossRef

6. Oktay B, Akbal E, Firat H, Ardic S, Akdemir R, Kizilgun M. Evaluation of the relationship between heart type fatty acid binding protein levels and the risk of cardiac damage in patients with obstructive sleep apnea syndrome. Sleep Breath 2008;12:223-8. CrossRef

7. Negishi K, Noiri E, Doi K, Maeda-Mamiya R, Sugaya T, Portilla D, et al. Monitoring of urinary L-type fatty acid-binding protein predicts histological severity of acute kidney injury. Am J Pathol 2009;174:1154-9.

8. Yavuz N, Unal E, Memisoglu K, Krand O, Kiziler AR, Aydemir B, et al. Plasma leptin levels in rats with pancreatitis. Tohoku J Exp Med 2004;204:243-8. CrossRef

9. Ek BA, Cistola DP, Hamilton JA, Kaduce TL, Spector AA. Fatty acid binding proteins reduce 15-lipoxygenase-induced oxygenation of linoleic acid and arachidonic acid. Biochim Biophys Acta 1997;1346:75-85.

10. Raza H, Pongubala JR, Sorof S. Specific high affinity binding of lipoxygenase metabolites of arachidonic acid by liver fatty acid binding protein. Biochem Biophys Res Commun 1989;161:448-55. CrossRef

11. Sztefko K, Panek J. Serum free fatty acid concentration in patients with acute pancreatitis. Pancreatology 2001;1:230-6. CrossRef

12. Kanaguchi Y, Suzuki Y, Osaki K, Sugaya T, Horikoshi S, Tomino Y. Protective effects of L-type fatty acid-binding protein (L-FABP) in proximal tubular cells against glomerular injury in anti-GBM antibody-mediated glomerulonephritis. Nephrol Dial Transplant 2011;26:3465-73. CrossRef

13. Matsui K, Kamijo-Ikemorif A, Sugaya T, Yasuda T, Kimura K. Renal liver-type fatty acid binding protein (L-FABP) attenuates acute kidney injury in aristolochic acid nephrotoxicity. Am J Pathol 2011;178:102132. CrossRef

14. Pongprasobchai S, Jianjaroonwong V, Charatcharoenwitthaya P, Komoltri C, Tanwandee T, Leelakusolvong S, et al. Erythrocyte sedimentation rate and $\mathrm{C}$-reactive protein for the prediction of severity of acute pancreatitis. Pancreas 2010;39:1226-30. CrossRef

15. Papachristou GI, Whitcomb DC. Predictors of severity and necrosis in acute pancreatitis. Gastroenterol Clin North Am 2004;33:871-90. CrossRef

16. Blum T, Maisonneuve P, Lowenfels AB, Lankisch PG. Fatal outcome in acute pancreatitis: its occurrence and early prediction. Pancreatology 2001;1:237-41. CrossRef

17. Pelsers MM, Hermens WT, Glatz JF. Fatty acid-binding proteins as plasma markers of tissue injury. Clin Chim Acta 2005;352:15-35. CrossRef 
KLINIK ÇALIŞMA - ÖZET

\section{Akut pankreatitli hastalarda serum L-FABP düzeylerinin değerlendirilmesi Dr. Erdem Koçak, ${ }^{1}$ Dr. Erdem Akbal, ${ }^{2}$ Dr. Seyfettin Köklü, ${ }^{3}$ Dr. Gürhan Adam ${ }^{4}$}

${ }^{1}$ Çanakkale Devlet Hastanesi, Gastroenteroloji Kliniği, Çanakkale;

${ }^{2}$ Çanakkale Onsekiz Mart Üniversitesi Tıp Fakültesi, Gastroenteroloji Kliniği, Çanakkale;

${ }^{3}$ Hacettepe Üniversitesi Tıp Fakültesi, Gastroenteroloji Kliniği, Ankara;

${ }^{4}$ Çanakkale Onsekiz Mart Üniversitesi Tıp Fakültesi, Radyoloji Kliniği, Çanakkale

AMAÇ: Bu çalışmanın amacı akut pankreatitli hastalarda serum L-FABP düzeylerini değerlendirmek ve sağlıklı olgular ile karşılaştırmak.

GEREÇ VE YÖNTEM: Çalışmaya akut pankreatit tanısı konulan 30 hasta ve yaş ve cinsiyeti benzer 30 sağlıklı olgu alındı. Serum L-FABP düzeyleri başvuru anında ve iyileşme döneminde değerlendirildi.

BULGULAR: Akut pankreatitli hastaların başvuru anında serum L-FABP düzeyleri kontrol grubundan belirgin olarak yüksekti $(4 \mathrm{I} 009.4 \mathrm{I} \pm 3240 \mathrm{I} .3 \mathrm{I}$ $\mathrm{pg} / \mathrm{ml}$ ve $17057.00 \pm 5015.74 \mathrm{pg} / \mathrm{ml}, \mathrm{p}=0.008$ ). Serum L-FABP düzeyleri iyileşme periyodunda başvuru düzeylerine göre düşmekle birlikte aradaki fark istatistiksel olarak anlamlı değildi. Bununla birlikte akut pankreatitli hastalarda serum L-FABP düzeyleri AST ve LDH düzeyleri ile korele idi. TARTIŞMA: Akut pankreatitli hastalarda yüksek L-FABP düzeyleri pankreatik mikrosirkulatuar bozukluk ile ilişkili olabilir. Bu sonuçlar serum LFABP düzeylerinin akut pankreatitte kullanılabilecek bir biyomarker olduğunu destekler niteliktedir.

Anahtar sözcükler: Akut pankreatit; serum L-FABP; tanı.

Ulus Travma Acil Cerrahi Derg 2015;2I(I):39-43 doi: 10.5505/tjtes.2015.49879 